\title{
Antioxidant Activity of Leaf Extract of Calotropis Procera Tree in Alkufra City
}

\author{
Naema M El Aali'*, Imperiyka Hammad ${ }^{2}$, Mona M Shpeek ${ }^{1}$ and Tehani I \\ Abobaker ${ }^{1}$ \\ ${ }^{1}$ Chemistry Department, Faculty of science, Benghazi University, Libya \\ ${ }^{2}$ Faculty of arts and science Alkufra, University of Benghazi
}

ISSN: 2576-8840

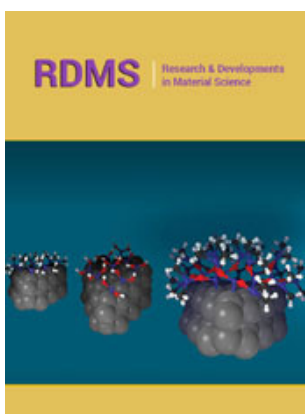

*Corresponding author: Naema M El Aali, Chemistry Department, Faculty of science, Benghazi University, Libya

Submission: 䧳 November 07, 2019

Published: 僵 November 15, 2019

Volume 12 - Issue 3

How to cite this article: Naema M El Aali, Imperiyka Hammad, Mona M Shpeek, Tehani I Abobaker. Antioxidant Activity of Leaf Extract of Calotropis Procera Tree in Alkufra City. Res Dev Material Sci. 12(3) RDMS.000786.2019.

DOI: 10.31031/RDMS.2019.12.000786

Copyright@ Naema M El Aali, This article is distributed under the terms of the Creative Commons Attribution 4.0 International License, which permits unrestricted use and redistribution provided that the original author and source are credited.

\begin{abstract}
Calotropis procera belongs to the family Asdepiadaceae, which has been used as a folk medicine. Although there are some reports showing the plant effective in folk use but there were no scientific reports for antioxidant activity of petroleum ether extract. The leaves of Calotropis procera were air dried, grounded and soaked with diethyl ether for 48 hours than the solvent was evaporated and the oil extract was investigated for antioxidant ability by measuring total phenolic content, total flavonid content and reducing ability, the data obtained were compared with Pyrogallol, Qurcetein and ascorbic acid which they consider as standard for these experiment. The result shows high antioxidant activity for Calotropis procera extract.
\end{abstract}

\section{Introduction}

Calotropis procera, Apocynaceae, belongs to the family Asdepiadaceae, It occurs in most parts of the tropical world, in dry sandy and alkaline soils, in waste land and grows abundantly as a weed [1], Calotropis gigantea is Worldwide known by various names such as swallowwort, dead-sea apple, sodom apple or milk weed. It has been widely used in the Sudanese, Unani, Arabic and Indian traditional medicinal system for the treatment of various diseases namely leprosy, ulcers, piles and diseases of the spleen, liver and abdomen [2]. Calotropis procera, a wild growing plant of family Asclepiadaceae, is well known for its medicinal properties. Different parts of this plant have been reported to exhibit anti-inflammatory, analgesic, and antioxidant properties. It is found in most parts of the world in dry, sandy and alkaline soils and warm climate and is more common in south western and central India and western Himalayas. It is found in waste lands and grows as a weed in agricultural lands. In ancient Ayurvedic medicines the plant Calotropis procera was known as "Rakta arka" [3]. Medicinally important parts of this plant are flower, terminal leaf pairs, root with root bark and latex. Out of that the most significant part which drew attention of researchers is latex because of its medicinal properties, economic use for cheese and rubber production. Latex contain majority of hydrocarbon contents have established this plant as a source of bio-energy. The plant also shows good antibacterial activity $3 \mathrm{M}$, all parts of the plant exude white latex when cut or broken. The latex contains a range of toxic compounds. These toxins are believed to have a role in the plant's defence against insects, mites and pathogens [4]. The latex has been reported to comprise chitinases, proteinases and anti-oxidative enzymes [5]. Calotropis species is used for the treatment of bronchitis, pain, asthma, leprosy, ulcers, piles, spleen, tumors, liver, abdomen and dyspepsia; it is also used frequently for cold, fever, diarrhea, rheumatism, indigestion, eczema and jaundice. Different parts of the plant were used for the treatment of several diseases such as stem for skin disease, intestinal worms, leprosy, leucoderma; the roots are used for the treatment of leprosy, asthma, cough, elephantiasis, rheumatism and diarrhea; latex and leaves are used for swelling and joint pain; oil massage can be used for paralyzed part; juice of Calotropis was used for purgation [6].

Free radicals are involved in many disorders like neurodegenerative diseases, cancer and AIDS. Antioxidants through their scavenging power are useful for the management of those diseases [7] Calotropis procera has a good antioxidant activity which can be efficiently used in the pharmaceutical purposes in arid regions of Rajasthan and world over [8]. The free radical scavenging property may be one of the mechanisms by which this drug is effective as 
a traditional medicine [9]. Thus, in this research, the antioxidant activity of Calotropis procera petrolium extract was investigated using different methods.

\section{Experimental Part}

\section{Plant collection and identification}

Samples of Calotropis procera were collected from Alkufra City in south of Libya, the botanical identification of Calotropis procera was determined with the aid of the description given by the Libyan Flora.

\section{Plant extraction}

Powdered plant $(140 \mathrm{~g})$ was extracted with $250 \mathrm{ml}$ of ethyl acetate by socking and shaking for $48 \mathrm{hrs}$. Then evaporated to dryness at $20-30{ }^{\circ} \mathrm{C}$ by Rotatory evaporator (RE2000).

\section{Chemicals}

Chemicals such as petroleum ether, copper sulfate, ascorbic acid and monobasic dihydrogen phosphate were obtained from Merck company, ferric chloride, sodium nitrite, aluminum chloride, sodium Chloride and sodium carbonate were obtained from Farmitalia Carloerba. Dibasic monohydrogen phosphate, trichloro acetic acid and sodium hydroxide were obtained from Redeal De Haennagtca. Potassium ferricyanide was obtained from NICE company.

\section{Total phenolic content}

The total phenolic content was determined using colorimetric method and expressed as Pyrogallol equivalents according to the method proposed by Singleton et al. in 1999. To 100 of 100, 200, 300,400 , and $500 \mathrm{mg} / \mathrm{L}$ of the different extracts $2 \mathrm{ml}$ of de-ionized water were added and mixed with " $600 " \mu l$ of Folin-Cicalteau reagent, the tube was allowed to stand at room temperature for $5 \mathrm{~min}$, and $2 \mathrm{ml}$ of $20 \%$ sodium carbonate were add and kept at boiling water bath for $1 \mathrm{~min}$, after cooling the blue color formed measured at $765 \mathrm{~nm}$ by Aquarins (CE700) spectrophotometer Cecil instruments [10].

\section{Reducing power assay}

This assay was determined according to the method of Oyaizu (1986). 2.5ml of 100, 200, 300, 400, and $500 \mathrm{mg} / \mathrm{L}$ Calotropis procera extracts were mixed with $2.5 \mathrm{ml}$ of $(0.2 \mathrm{M}, \mathrm{pH} 6.6)$ sodium phosphate buffer and $2.5 \mathrm{ml}$ of $1 \%$ potassium ferricyanide $\left[\mathrm{K}_{3} \mathrm{Fe}(\mathrm{CN})_{6}\right]$, then the mixture was incubated at $50{ }^{\circ} \mathrm{C}$ for $20 \mathrm{~min}$. $2.5 \mathrm{ml}$ of $10 \%$ trichloroacetic acid $(\mathrm{w} / \mathrm{v})$ were added, the mixture was centrifuged at 1000rpm for 8min (Centorion K240R-2003 refrigerated centrifuge). The upper layer $(5 \mathrm{ml})$ was mixed with $5 \mathrm{ml}$ of de-ionised water and $1 \mathrm{ml}$ of $0.1 \%$ of ferric chloride, and the absorbance was measured spectrophotometrically at $700 \mathrm{~nm}$. Ascorbic acid was used to produce the calibration curve [11].

\section{Total flavonoid content by spectrophotometer}

The determination of total flavonoids was performed according to the colorimetric assay. $4 \mathrm{ml}$ of de-ionized water was added to $1 \mathrm{ml}$ of $100,200,300,400$, and $500 \mathrm{mg} / \mathrm{L}$ of the different extracts of the sample. $0.3 \mathrm{ml}$ of $5 \%$ sodium nitrite solution were added followed by $0.3 \mathrm{ml}$ of $10 \%$ aluminum chloride solution. The mixture was incubated at ambient temperature for $5 \mathrm{~min}$, and then $2 \mathrm{ml}$ of $1 \mathrm{M}$ sodium hydroxide were added to the mixture. Immediately, the volume of reaction mixture was made to $10 \mathrm{ml}$ with de-ionized water. The absorbance of the pink color developed was determined at $510 \mathrm{~nm}$. A calibration curve was prepared with quercetin and the results were expressed as mg quercetin equivalents per gram dry weight of sample [12].

\section{Results and Discussion}

\section{Total phenolic content}

Folin - Ciocalteu (F.C) reagent was used to determine total poly-phenol in sample extracts. This reagent oxidises phenolates, resulting in the production of complex molybdenum-tungsten blue which can be detected spectrophoto-metrically at $765 \mathrm{~nm}$. Folin-Cicalteau reagent is employed routinely in studying phenolic antioxidants [13]. For the Calotropis procera diethyl ether extract the amount of phenolic content were compared to Pyrogallol, which is a highly phenolic natural compound in which our extract showed higher phenolic content than the pyrgallol . These data were compared with study done on N. Sampath Kumar and V. Balamurugan in 2015 and our results were almost like them (Table 1; Figure 1).

Table 1: Total phenolic cotenant for pyrogallol and Calotropis procera petroleum ether extract.

\begin{tabular}{|c|c|c|}
\hline & \multicolumn{2}{|c|}{ Mean \pm Standard Deviation } \\
\hline Conc. " $\mu \mathrm{g} / \mathrm{ml}$ " & Pyrogallol & Petroleum Ether \\
\hline 100 & $0.292 \pm 0.005$ & $1.792 \pm 0.019$ \\
\hline 200 & $0.494 \pm 0.003$ & $1.842 \pm 0.007$ \\
\hline 300 & $0.797 \pm 0.007$ & $2.413 \pm 0.012$ \\
\hline 400 & $0.857 \pm 0.002$ & $2.436 \pm 0.026$ \\
\hline 500 & $1.022 \pm 0.005$ & $2.461 \pm 0.014$ \\
\hline
\end{tabular}

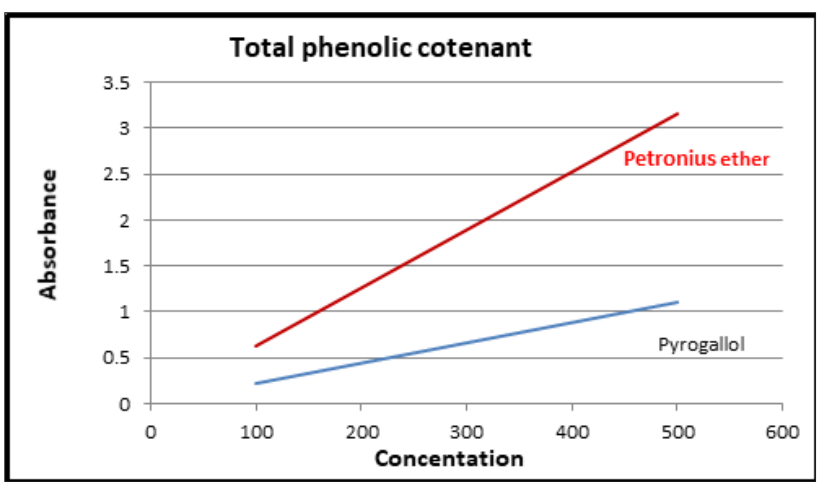

Figure 1: Total phenolic values of calotropis procera petroleum ether extract and pyrogallol.

\section{Reducing power assay}

The presence of reducers (i.e. antioxidants) causes the conversion of the $\mathrm{Fe}^{+3} /$ ferricyanide complex used in this method 
to the $\mathrm{Fe}^{+2} /$ ferrous form. Therefore, by measuring the formation of Perl's Prussian blue at $700 \mathrm{~nm}$, we can monitor the $\mathrm{Fe}^{+2}$ concentration; a higher absorbance at 700nm indicates a higher reducing power [14]. All data were compared to Ascorbic acid which has high reducing power ability and the result shows high reducing power assay for our extract. These data were compared with other published studies on Calotropis procera antioxidant activity, our data showed almost similar result reported by Remya Mohanra in 2012 (Table 2; Figure 2).

Table 2: Reducing power assay for ascorbic acid and Calotropis procera petroleum ether extract.

\begin{tabular}{|c|c|c|}
\hline \multirow{2}{*}{ Conc." $\mu \mathrm{g} / \mathrm{ml}$ " } & Mean \pm Standard Deviation \\
\hline 100 & $0.293 \pm 0.012$ & $0.913 \pm 0.017$ \\
\hline 200 & $0.382 \pm 0.032$ & $0.967 \pm 0.012$ \\
\hline 300 & $0.445 \pm 0.008$ & $1.060 \pm 0.056$ \\
\hline 400 & $0.693 \pm 0.10$ & $1.603 \pm 0.292$ \\
\hline 500 & $0.992 \pm 0.005$ & $1.737 \pm 0.062$ \\
\hline
\end{tabular}

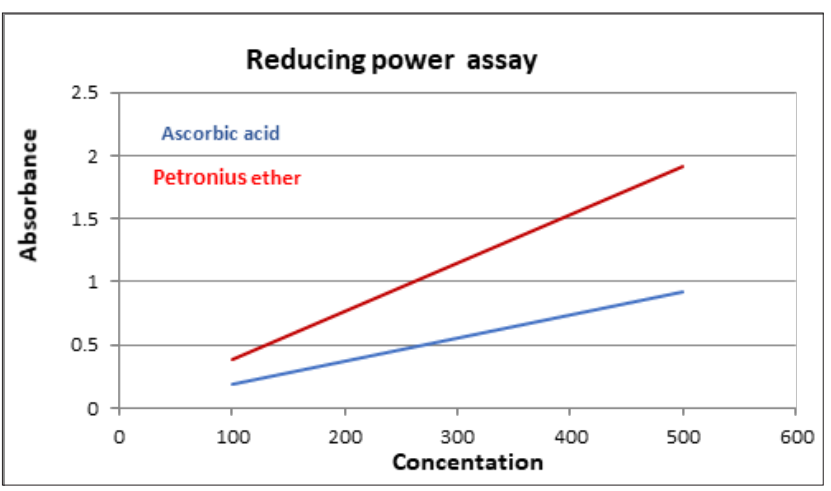

Figure 2: Reducing power assay for ascorbic acid and Calotropis procera petroleum ether extract.

\section{Total flavonoid content}

Table 3: Total flavonoid content of qurecetin and calotropis procera petroleum ether extract.

\begin{tabular}{|c|c|c|}
\hline & \multicolumn{2}{|c|}{ Mean \pm Standard Deviation } \\
\hline Conc." $\mu \mathrm{g} / \mathrm{ml} "$ & Quercetin & Petroleum Ether \\
\hline 100 & $0.236 \pm 0.003$ & $1.054 \pm 0.399$ \\
\hline 200 & $0.337 \pm 0.026$ & $1.41 \pm 0.060$ \\
\hline 300 & $0.442 \pm 0.087$ & $1.516 \pm 0.030$ \\
\hline 400 & $0.542 \pm 0.004$ & $1.524 \pm 0.045$ \\
\hline 500 & $0.588 \pm 0.006$ & $1.808 \pm 0.047$ \\
\hline
\end{tabular}

Total flavonoids can be determined in the sample extracts by reaction with sodium nitrite, followed by the development of colored flavonoid-aluminum complex using aluminum chloride which can be monitored spectrophoto- metrically at 510nm [13]. All data were compared to Quercetin, which is a flavonoid natural standard and the result shows higher flavonoid content for our extract. These results were compared with the result obtained by N. Sampath Kumar and V. Balamurugan in 2015 and were almost similar (Table 3; Figure 3).

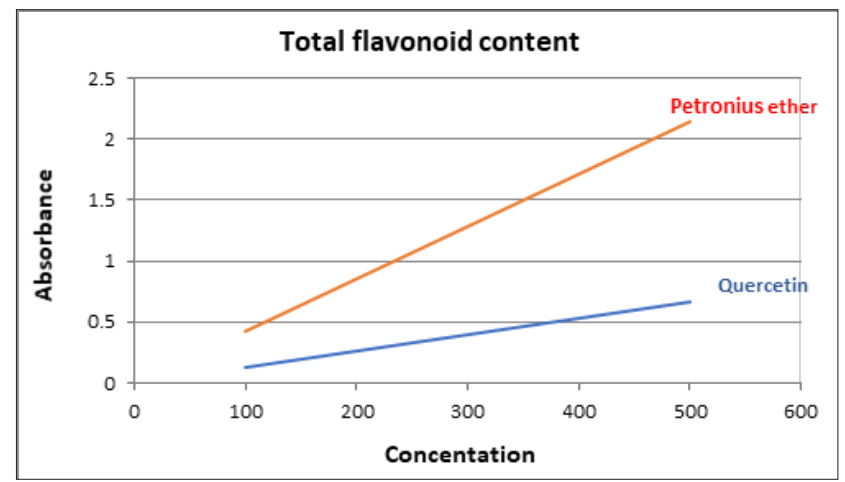

Figure 3: Total flavonoid content of qurecetin and calotropis procera petroleum ether extract.

\section{Conclusion}

In our scientific research we measure the antioxidant activity of extracted Calotropis proca oil and the result showed good antioxidant activity for the extracted oil. And we recommend doing more research to prove the antibacterial activity.

\section{References}

1. Mainasara MM, Aliero BL, Aliero AA, Yakubu M (2012) Phytochemical and antibacterial properties of root and leaf extracts of calotropis procera. Nigerian Journal of Basic and Applied Science 20(1): 1-6.

2. Oloum H (2014) Phytochemistry and ethno-pharmaceutics of calotropis procera. Ethno-Pharmaceutical products 1(2): 1-8.

3. Abhishek D, Mohit C, Ashish G, Ameeta (2010) Medicinal utility of Calotropis procera (Ait.) R. Br. as used by natives of village Sanwer of Indore District, Madhya Pradesh. International Journal of Pharmacy \& Life Sciences 1(3): 188-190.

4. Dhileepan K (2014) Prospects for the classical biological control of calotropis procera (Apocynaceae) using coevolved insects. Biocontrol Science and Technology 24(9): 977-988.

5. Taghvaei M, Sadeghi H, Khaef N (2015) Cardinal temperatures for germination of the medicinal and desert plant, calotropis procera. Planta Daninha 33(4).

6. Shripad MB, Ritu G, Jalindar PG (2018) Pharmacology of natural products: A recent approach on calotropis gigantea and Calotropis procera 59(1): 37-44.

7. Mohanraj R, Usmani MA (2012) Antioxidant activity of the leaf extracts of calotropis procera. International Journal of Advanced Biotechnology Research 2(1): 47-52.

8. Loonker S, Qadri WA, Singh S (2015) Antioxidant activity (in-vitro) of calotropis procera extract from arid regions of Rajasthan. IJCRR 7(19): 55-59.

9. Yesmin MN, Uddin SN, Mubassara S, Akond MA (2008) Antioxidant and antibacterial activities of calotropis procera linn. American-Eurasian J Agric \& Environ Sci 4(5): 550-553. 
10. Swan T, Hillis WE (1959) The phenolic constituents of prunu domestica 1. The Quantitative Analysis of Phenolic Constituents Journal of the Science of Food and Agericulture 10(1): 63-68.

11. Oyaizu M (1986) Studies on product of browning reaction prepared from glucose amine. Japanese Journal of Nutrition 44(6): 307-315.

12. Zhishen J, Mengcheng T, Jianming W (1999) The determination of flavonoid contents in mulberry and their scavenging effects on superoxide radicals. Food Chem 64(4): 555-559.
13. Rajurkar NS, Gaikwad K (2012) Evaluation of phytochemicals, antioxidant activity and elemental content of Adiantum capillus veneris leaves. Journal of Chemical and Pharmaceutical Research 4(1): 365-374.

14. Barros L, Ferreira M, Queiros B, Ferreira I, Baptista P (2007) Total phenols, ascorbic acid, b-carotene and lycopene in Portuguese wild edible mushrooms and their antioxidant activities. Food Chemistry 103: 413-419. 